\title{
First record of Leptoomus janzeni Gibson (Hymenoptera, Chalcidoidea) from Rovno amber
}

\author{
Serguei A. Simutnik', Evgeny E. Perkovsky', Dmitry V. Vasilenko ${ }^{2,3}$ \\ I I.I. Schmalhausen Institute of Zoology, National Academy of Sciences of Ukraine, Kiev, 01601 Ukraine \\ 2 Borissiak Paleontological Institute, Russian Academy of Sciences, Moscow, 117647 Russia 3 Cherepovets State \\ University, Lunacharsky Avenue, 5, Cherepovets, 162600 Russia
}

Corresponding author: Serguei A. Simutnik (simutnik@gmail.com)

Academic editor: P. Jansta | Received 22 September 2020 | Accepted 18 November 2020 | Published 29 December 2020

http://zoobank.org/AC95CBDE-AA85-4A7D-9B42-4B1CA032AEDB

Citation: Simutnik SA, Perkovsky EE, Vasilenko DV (2020) First record of Leptoomus janzeni Gibson (Hymenoptera, Chalcidoidea) from Rovno amber. Journal of Hymenoptera Research 80: 137-145. https://doi.org/10.3897/jhr.80.58882

\begin{abstract}
The large and distinctive chalcidoid wasp Leptoomus janzeni Gibson, 2008, originally described from late Eocene Baltic amber, is newly recorded from coeval Rovno amber (Ukraine) based on a single wellpreserved female specimen. Only 66 species of Rovno hymenopterans (49\%) are also known from Baltic amber. High resolution photomicrographs and measurements of the specimen are given. Some character states of the new specimen, such as a green metallic coloration, a bare and flat prepectus, location and number of multiporous plate sensillae on the flagellum, sclerotized spur vein of the hind wing, and two metatibial spur are reported in this species for the first time.
\end{abstract}

\section{Keywords}

Baltic amber, Eocene, prepectus, spur vein, Ukraine

\section{Introduction}

Chalcidoidea (Hymenoptera) are currently divided into 23 extant families (Heraty et al. 2013; Janšta et al. 2018). Members of the families Cynipencyrtidae, Encyrtidae, Eupelmidae (except male Eupelminae), and Tanaostigmatidae share an enlarged, convex mesopleuron (acropleuron sensu Gibson 1986) and several other correlated 
adaptations hypothesized to enhance jumping ability (Gibson 1986). It has sometimes been suggested that these taxa constitute a monophyletic group based on this enlarged mesopleuron (Trjapitzin 1968, 1989; LaSalle 1987). However, Gibson (1989) did not find any putative synapomorphies for the group as he defined it, and the morphological analysis of Heraty et al. (2013) retrieved the group as a monophyletic only if Oodera Westwood (Pteromalidae: Cleonyminae) was included. The combined morphologicalmolecular results of Heraty et al. (2013) did not retrieve this group as monophyletic, nor did the transcriptome-based phylogenies of Peters et al. (2018) and Zhang et al. (2020), suggesting that adaptations for jumping evolved independently.

Here, we report a large and well-preserved female from Rovno amber that we treat as conspecific with Leptoomus janzeni Gibson, 2008 (Chalcidoidea), originally described from Baltic amber. Gibson (2008) did a detailed analysis of the morphology of L. janzeni and compared it with that of Cynipencyrtus Ishii, 1928 (Cynipencyrtidae), Encyrtidae, Eupelmidae, and Tanaostigmatidae. This suggested that Leptoomus is likely in or near Clade E, sensu Heraty et al. (2013), the chalcid "jumpers" with an enlarged acropleuron. Gibson (2008, p. 24) proposed: "until evolutionary relationships of the treated taxa are established more confidently by such studies it seems prudent to classify L. janzeni along with Cynipencyrtus in Tanaostigmatidae". Members of Tanaostigmatidae are distinguished in particular by an enlarged, bulbous prepectus projecting anteriorly beside the pronotum that resembles the prepectal structure of L. janzeni (Figs 1B, C, 2A: pre).

\section{Material and methods}

Ukrainian Rovno amber (Priabonian stage, 33.9-37.8 Mya) is the southern coeval of Baltic amber, from which L. janzeni was described. The amber containing the specimen of L. janzeni was found at the village of Velyki Telkovichi (Vladimirets Distr., Rovno Region, Ukraine) and is housed at the Schmalhausen Institute of Zoology of the National Academy of Sciences of Ukraine, Kiev (SIZK). The localities and composition of the Rovno amber fauna were recently characterized in a series of reviews by Perkovsky et al. (2010), Jałoszyński and Perkovsky (2016), Perkovsky $(2016,2018)$ and Martynova et al. (2019). Including Ektopicercus punctatus Simutnik (Simutnik and Perkovsky 2020), and L. janzeni, 135 species of Hymenoptera are now known from Rovno amber, with 66 (49\%) in common with Baltic amber (Radchenko and Perkovsky 2020; this paper).

Nearly all studied Rovno amber inclusions from Rovno Region were collected from Klesov and the Horyn River Basin (Perkovsky et al. 2010; Perkovsky 2017) except new collections from the more western basins of the Styr and Stokhod rivers and especially the Veselukha River floodplain between them (Lyubarsky and Perkovsky 2020). These new collections (mostly from Voronki and Velyki Telkovichi) revealed a number of new species of beetles, neuropterans and snakeflies (Jałoszyński and Perkovsky 2019; Legalov et al. 2019; Colombo et al. 2020; Perkovsky and Makarkin 2019, 
2020; Makarkin and Perkovsky 2020; Lyubarsky and Perkovsky 2020; Radchenko and Khomich 2020; Perkovsky et al. 2020) as well as new mosses and liverworts (Mamontov et al. 2020 and references therein), including the first named amber Sphagnum from Velyki Telkovichi and some species previously recorded from Baltic amber (Perkovsky and Olmi 2018; Martynova et al. 2019; Mamontov et al. 2020) or from Baltic and Bitterfeld ambers (Radchenko and Perkovsky 2018, 2020).

Photographs were taken using a Leica Z16 APO stereomicroscope with a Leica DFC 450 camera and processed with LAS V3.8 software. To improve imaging, we applied sucrose syrup of approximately the same refractive index as the amber and placed a glass coverslip on top; after photography, the syrup was removed using warm water. Some images were then enhanced (brightness and contrast only) using Adobe Photoshop.

Terminology and abbreviations follow Gibson (1997), Noyes et al. (1997), and Heraty et al. (2013). The following abbreviations are used in the text and illustrations:

OOL minimum distance between an eye margin and the adjacent posterior ocellus;

POL minimum distance between the posterior ocelli;

OCL minimum distance between a posterior ocellus and the occipital margin;

LOL minimum distance between the anterior ocellus and a posterior ocellus;

F1, F2, etc. funicular segments 1, 2, etc.;

mps multiporous plate sensilla;

mspl mesopleuron;

pre prepectus;

spv spur vein.

\section{Results}

Taxonomy

Chalcidoidea Latreille, 1817

\section{Leptoomus janzeni Gibson, 2008}

Figs 1, 2A-E

Material examined. SIZK VT-95, 1 , , Velyki Telkovichi, Rovno amber; late Eocene. The inclusion is in a clear amber piece (about of $30 \times 14 \times 8 \mathrm{~mm}$ ) of irregular shape (Fig. 1A). A syninclusion consists of a precariously preserved small insect with only the legs visible.

Measurements. Body length $2.45 \mathrm{~mm}$; other reported measurements are relative (one micrometer division $=0.014 \mathrm{~mm}$ ) and are approximate because of optical effects in the amber.

Head. Head length 26, width 46, height 38; eye height 15; malar space 15; posterior ocellus diameter 3; OOL 1.5; POL 7; OCL 6; LOL 5; distance between toruli 7 , 


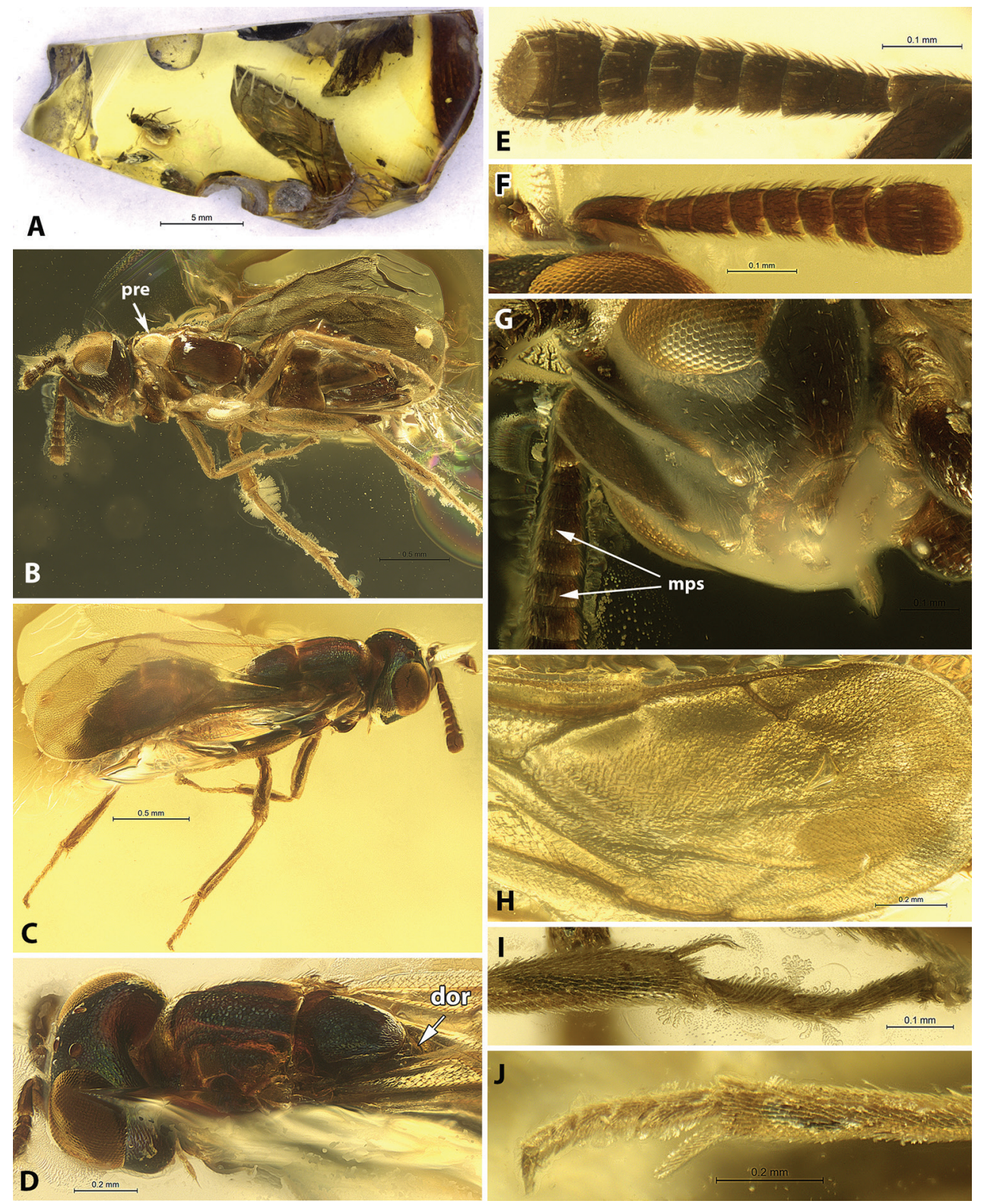

Figure I. Leptoomus janzeni, female VT-95 from Rovno amber (deposed in SIZK) A piece of amber containing the specimen $\mathbf{B}$ habitus ventrolateral (left side) $\mathbf{C}$ habitus dorsolateral (right side) $\mathbf{D}$ head and mesosoma dorsolateral, dorsellum $\mathbf{E}$ antenna ventral $\mathbf{F}$ antenna dorsal $\mathbf{G}$ head frontolateroventral, part of antenna with mps arrowed $\mathbf{H}$ forewing $\mathbf{I}$ protibial spur, protarsus $\mathbf{J}$ mesotibial spur, mesotarsus.

between torulus and eye 9, from torulus to mouth margin 6; length to width ratio of scape 25:7, pedicel 8:4, F1 2:4, F2 3:4.5, F3 4:5, F4 3:5, F5 3:5.5, F6 3:6, F7 3:7 (very approximately), clava 7.5:10, micropilose sensory region 5:7.5. 


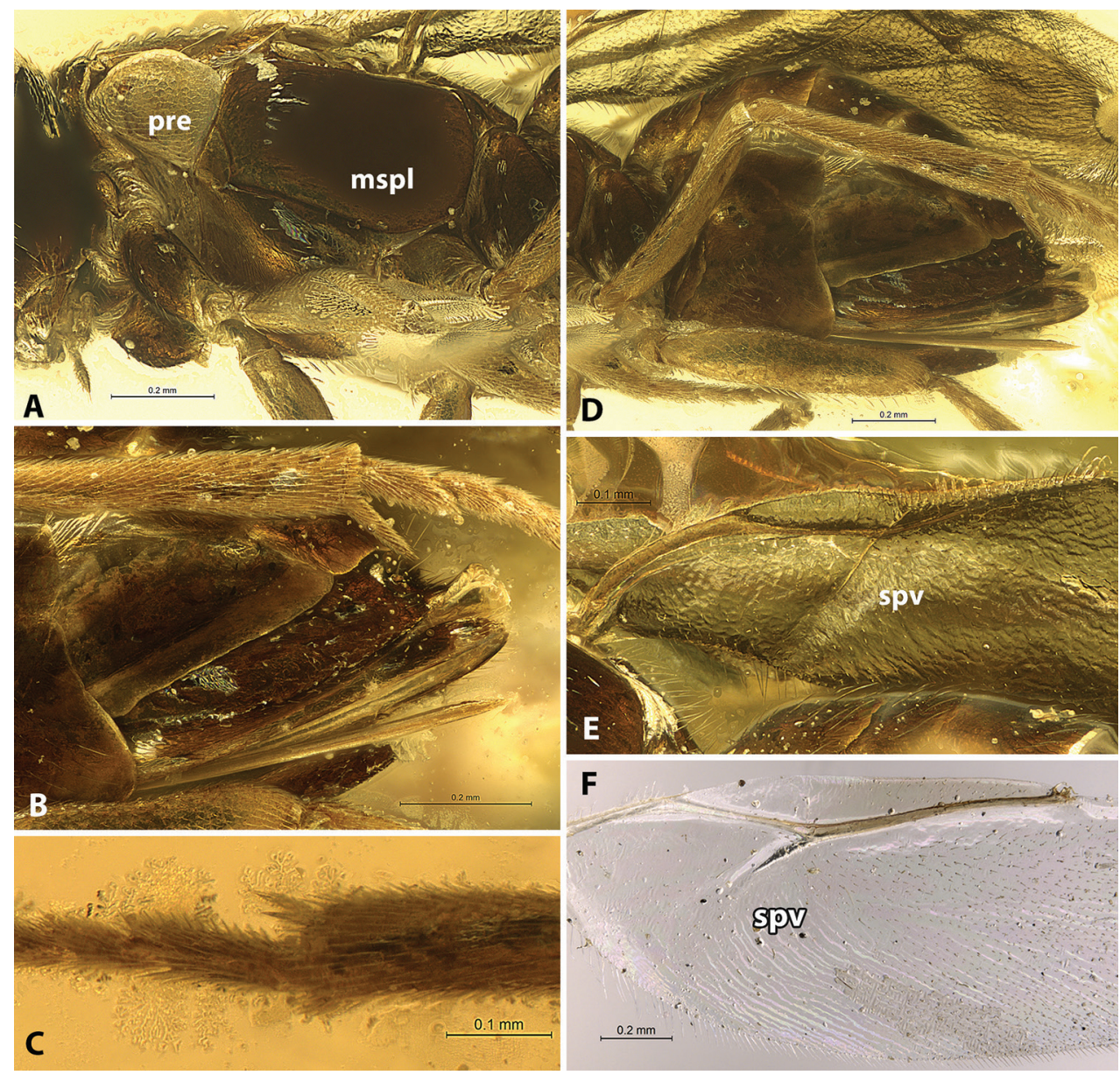

Figure 2. A-E L. janzeni, female $\mathbf{A}$ mesosoma ventrolateral $\mathbf{B}$ apex of metasoma lateroventral $\mathbf{C}$ metatibial apex with two spurs D metasoma lateral E venation of hind wing with spur vein $\mathbf{F}$ Pentacladia sp., female, venation of hind wing.

Mesosoma. Mesosoma length 68; length to width ratio of mesoscutum 30:30, scutellum 26:21; prepectus maximal length 16, height 15.

Appendages. Length to width ratio of fore wing 120:55; mv:pmv:stv about $22: 18: 15$; length to width ratio of hind wing $77: 25$; protibia 30 , protibial spur (calcar) 8; mesotibia 48, mesobasitarsus 12, mesotibial spur 11.

Metasoma. Length 77, height 45 (lateral view), width 45; ovipositor stylet from hypopygium margin 41 .

Comparison with $L$. janzeni type material. The Rovno amber specimen differs from the Baltic amber material by having slightly infuscate, brownish, rather than hyaline forewings. The head and thorax have a distinct green metallic sheen not seen in the Baltic specimen (Figs 1C, D). Multiporous plate sensilla on the flagellum were not described by Gibson (2008), but are visible in the Rovno specimen on F3-F7, and on 
the apical two segments of the 3-segmented clava (Figs. 1E, F, G); F4 appear to have only a single mps but the others have multiple mps in a single row per segment that does not fully encircle the segment.

Also, in the Rovno specimen the spur vein originating from the marginal venation of the hind wing is visible (Fig. 2E: spv). In addition to Tanaostigmatidae, some Pteromalidae (for example, Nasonia), and some Eupelmidae (e.g. Pentacladia, Fig. 2F: spv) also have a similar sclerotized spur vein.

The only uniquely shared feature of L. janzeni and Tanaostigmatidae is that in both the prepectus extends anteriorly, exterior to pronotum, though in L. janzeni it is flatter and its lateral panel is bare (Figs 1B, 2A: pre).

The metatibia of the new specimen has two spurs (Fig. 2C). This character L. janzeni shares the with many other chalcidoid taxa.

The metanotum is not clearly visible because the wings are positioned over the gaster. The dorsellum (Fig. 1D: dor) appears to taper posteriorly to fit into a broadly incised anterior margin of the propodeum such that the medial length of the dorsellum is greater than the medial length of the propodeum.

\section{Conclusions}

The set of morphological features possessed by L. janzeni places the taxon in the "jumpers" Clade E sensu Heraty et al. (2013). As previously shown by Gibson (2008), L. janzeni appears to be close to Tanaostigmatidae. To establish the position of $L$. janzeni on the chalcidoid tree, further research is needed with additional fossil and molecular data.

\section{Acknowledgements}

We are grateful to Gary A.P. Gibson (Canadian National Collection of Insects, Arachnids and Nematodes, Agriculture and Agri-Food Canada) for confirming the correctness of the determination of the L. janzeni and valuable comments; Anatoly P. Vlaskin (SIZK) for cutting and polishing the sample, Bruce Archibald (Simon Fraser University, Burnaby, Canada) for editing of the English. The authors are thankful to the editor Petr Janšta and to an anonymous reviewer for corrections. The study was supported by the National Research Foundation of Ukraine grant "Leading and Young Scientists Research Support" (registration number 2020.02 / 0369) for the first author.

\section{References}

Colombo WD, Gobbi FT, Perkovsky EE, Azevedo CO (2020) Synopsis of the fossil Pristocerinae (Hymenoptera, Bethylidae), with description of two new genera and species from Burmese, Taimyr, Baltic and Rovno ambers. Historical Biology. https://doi.org/10.1080/089 12963.2020.1733551 
Gibson GAP (1986) Mesothoracic skeletomusculature and mechanics of flight and jumping in Eupelminae (Hymenoptera, Chalcidoidea: Eupelmidae). Canadian Entomologist 118(7): 691-728. https://doi.org/10.4039/Ent118691-7

Gibson GAP (1989) Phylogeny and classification of Eupelmidae, with a revision of the world genera of Calosotinae and Metapelmatinae (Hymenoptera: Chalcidoidea). Memoirs of the Entomological Society of Canada 149: 1-121. https://doi.org/10.4039/entm121149fv

Gibson GAP (1997) Chapter 2, Morphology and terminology. In: Gibson GAP, Huber JT, Woolley JB (Eds) Annotated keys to the genera of Nearctic Chalcidoidea (Hymenoptera). NRC Research Press, Ottawa, 16-45.

Gibson GAP (2008) Description of Leptoomus janzeni, n. gen. and n. sp. (Hymenoptera: Chalcidoidea) from Baltic amber, and discussion of its relationships and classification relative to Eupelmidae, Tanaostigmatidae and Encyrtidae. Zootaxa 1730: 1-26. https://doi. org/10.11646/zootaxa.1730.1.1

Gibson GAP (2017) Revision of Eopelma Gibson (Hymenoptera: Chalcidoidea: Eupelmidae: Neanastatinae). Proceedings of the Entomological Society of Washington 119 (Special Issue): 741-777. https://doi.org/10.4289/0013-8797.119.SpecialIssue.741

Heraty JM, Burks RA, Cruaud A, Gibson GA, Liljeblad J, Munro J, Rasplus JY, Delvare G, Janšta P, Gumovsky A, Huber JT, Woolley JB, Krogmann L, Heydon S, Polaszek A, Schmidt S, Darling DC, Gates MW, Mottern J, Murray E, Dal Molin A, Triapitsyn S, Baur H, Pinto JD, Van Noort S, George J, Yoder M (2013) A phylogenetic analysis of the megadiverse Chalcidoidea (Hymenoptera). Cladistics 29: 466-542. https://doi.org/10.1111/cla.12006 Jałoszyński P, Perkovsky EE (2016) Diversity of Scydmaeninae (Coleoptera: Staphylinidae) in Upper Eocene Rovno amber. Zootaxa 4157(1): 1-85. https://doi.org/10.11646/zootaxa.4157.1.1

Jałoszyński P, Perkovsky EE (2019) The Mastigitae genus $\dagger$ Baltostigus in Upper Eocene Rovno amber (Coleoptera: Staphylinidae: Scydmaeninae). Zootaxa 4661(3): 594-600. https:// doi.org/10.11646/zootaxa.4661.3.12

Janšta P, Cruaud A, Delvare G, Genson G, Heraty JM, Kř́žková B, Rasplus JY (2018) Torymidae (Hymenoptera, Chalcidoidea) revised: molecular phylogeny, circumscription and reclassification of the family with discussion of its biogeography and evolution of life-history traits. Cladistics 34: 627-651. https://doi.org/10.1111/cla.12228

LaSalle J (1987) New World Tanaostigmatidae (Hymenoptera, Chalcidoidea). Contributions of the American Entomological Institute 23(1): 1-181.

Legalov AA, Nazarenko VYu, Perkovsky EE (2019) New weevils (Coleoptera: Curculionidae) from Rovno amber. Paleontological Journal 53(10): 1045-1059. https://doi.org/10.1134/ S0031030119100101

Lyubarsky GYu, Perkovsky EE (2020) First Rovno amber species of the genus Telmatophilus (Coleoptera: Clavicornia: Cryptophagidae) from Veselukha floodplain. Invertebrate Zoology 17(1): 25-35. https://doi.org/10.15298/invertzool.17.1.03

Makarkin VN, Perkovsky EE (2020) A new species of Proneuronema (Neuroptera: Hemerobiidae) from late Eocene Rovno amber, Zootaxa 4718(2): 292-300. https://doi.org/10.11646/ zootaxa.4718.2.11

Mamontov YuS, Atwood JJ, Perkovsky EE, Ignatov MS (2020) Hepatics from Rovno amber (Ukraine): Frullania pycnoclada and a new species, F. vanae. The Bryologist 123(3): 421430. https://doi.org/10.1639/0007-2745-123.3.421 
Martynova KV, Perkovsky EE, Olmi M, Vasilenko DV (2019) New records of Upper Eocene chrysidoid wasps (Hymenoptera: Chrysidoidea) from basins of Styr and Stokhod rivers (Rovno amber). Paleontological Journal 53(10): 998-1023. https://doi.org/10.1134/ S0031030119100125

Noyes JS, Woolley JB, Zolnerowich G (1997) Chapter 8. Encyrtidae. In: Gibson GAP, Huber JT, Woolley JB (Eds) Annotated Keys to the Genera of Nearctic Chalcidoidea (Hymenoptera). NRC Research Press, Ottawa, 170-320.

Perkovsky EE (2016) Tropical and Holarctic ants in Late Eocene ambers. Vestnik zoologii 50(2): 111-122. https://doi.org/10.1515/vzoo-2016-0014

Perkovsky EE (2017) Rovno amber caddisflies (Insecta, Trichoptera) from different localities, with information about three new sites. Vestnik zoologii 51(1): 15-22. https://doi. org/10.1515/vzoo-2017-0003

Perkovsky EE (2018) Only a half of species of Hymenoptera in Rovno amber is common with Baltic amber. Vestnik zoologii 52(5): 353-360. https://doi.org/10.2478/vzoo-2018-0037

Perkovsky EE, Makarkin VN (2019) A new species of Succinoraphidia Aspöck \& Aspöck, 2004 (Raphidioptera: Raphidiidae) from the late Eocene Rovno amber, with venation characteristics of the genus. Zootaxa 4576(3): 570-580. https://doi.org/10.11646/zootaxa.4576.3.9

Perkovsky EE, Makarkin VN (2020) A new species of Sympherobius Banks (Neuroptera: Hemerobiidae) from the late Eocene Rovno amber. Palaeoentomology 3(2): 196-203.

Perkovsky EE, Olmi M (2018) Discovery of the first pincer wasp (Hymenoptera, Dryinidae) from Rovno amber. Zootaxa 4457(2): 296-304. https://doi.org/10.11646/zootaxa.4457.2.5

Perkovsky EE, Olmi M, Vasilenko DV, Capradossi L, Guglielmino A (2020) The first species of Bocchus Ashmead (Hymenoptera: Dryinidae) from Upper Eocene Rovno amber: B. schmalhauseni sp. nov. Zootaxa 4819(3): 544-556. https://doi.org/10.11646/zootaxa.4819.3.6

Perkovsky EE, Zosimovich VYu, Vlaskin AP (2010) Rovno amber. In: Penney D (Ed.) Biodiversity of fossils in amber from the Major World Deposits. Siri Sciences Press, Manchester, 116-136.

Peters R, Niehui O, Gunkel S, Bläser M, Mayer C, Podsiadlowski L, Kozlov A, Donath A, van Noort S, Liu Sh, Zhou X, Misof B, Heraty J, Krogmann L (2018) Transcriptome sequence-based phylogeny of chalcidoid wasps (Hymenoptera: Chalcidoidea) reveals a history of rapid radiations, convergence, and evolutionary success. Molecular Phylogenetics and Evolution 120: 286-296. https://doi.org/10.1016/j.ympev.2017.12.005

Radchenko AG, Khomych MR (2020) Ants of the extinct genus Cataglyphoides Dlussky, 2008 (Hymenoptera: Formicidae: Formicinae) from the late Eocene European ambers. Invertebrate Zoology 17(2): 154-161. https://doi.org/10.15298/invertzool.17.2.05

Radchenko AG, Perkovsky EE (2018) First record of fossil ant species Eocenomyrma rugosostriata (Mayr) (Hymenoptera: Formicidae) from the Rovno amber. Russian Entomological Journal 27(3): 285-288. https://doi.org/10.15298/rusentj.27.3.08

Radchenko AG, Perkovsky EE (2020) New records of the fossil ant genus Prionomyrmex Mayr (Hymenoptera, Formicidae, Myrmeciinae) from Late Eocene European ambers. Paleontologicheskii Zhurnal 2020(6): 60-67. [in Russian] [Translated: Paleontological Journal 54(6): 617-626] https://doi.org/10.1134/S0031030120060088 
Simutnik SA, Perkovsky EE (2020) Ektopicercus Simutnik gen. nov. (Hymenoptera, Chalcidoidea, Encyrtidae) from late Eocene Rovno amber. Palaeoentomology 3(4): 342-346. https://doi.org/10.11646/palaeoentomology.3.4.3

Trjapitzin VA (1968) The problems of morphological evolution and the classification of the family Encyrtidae (Hymenoptera, Chalcidoidea). Lectures in memory of N.A. Kholodkovsky 1967: 44-62. [in Russian]

Trjapitzin VA (1989) Parasitic Hymenoptera of the fam. Encyrtidae of Palaearctics. Opredeliteli po faune SSSR izdavaemiye Zoologicheskim institutom AN SSSR 158: 1-489. [in Russian]

Zhang J, Lindsey ARI, Peters RS, Heraty JM, Hopper KR, Werren JH, Martinson EO, Woolley JB, Yoder MJ, Krogmann L (2020) Conflicting signal in transcriptomic markers leads to a poorly resolved backbone phylogeny of chalcidoid wasps. Systematic Entomology 45(4): 783-802. https://doi.org/10.1111/syen.12427 